\title{
'n Praktykbenadering tot geloofsvorming vanuit die benadering van Thomas Groome en die Gestaltteorie: 'n Prakties-teologiese dialoog
}

\begin{tabular}{|c|c|}
\hline \multicolumn{2}{|c|}{$\begin{array}{l}\text { Authors: } \\
\text { Siegfried W. Louw }{ }^{1} \\
\text { Rudy A. Denton } \\
\text { Herman B. Grobler }\end{array}$} \\
\hline \multicolumn{2}{|c|}{$\begin{array}{l}\text { Affiliations: } \\
{ }^{1} \text { Faculty of Theology, } \\
\text { Potchefstroom Campus, } \\
\text { North-West University, South } \\
\text { Africa }\end{array}$} \\
\hline \multicolumn{2}{|c|}{$\begin{array}{l}{ }^{2} \text { Unit for Reformed Theology, } \\
\text { North-West University, South } \\
\text { Africa }\end{array}$} \\
\hline \multicolumn{2}{|c|}{$\begin{array}{l}{ }^{3} \text { Community Psychosocial } \\
\text { Research, North-West } \\
\text { University, South Africa }\end{array}$} \\
\hline \multicolumn{2}{|c|}{$\begin{array}{l}\text { Corresponding author: } \\
\text { Rudy Denton, } \\
\text { rudydenton@vodamail.co.za }\end{array}$} \\
\hline \multicolumn{2}{|c|}{$\begin{array}{l}\text { Dates: } \\
\text { Received: } 11 \text { Sept. } 2015 \\
\text { Accepted: } 02 \text { Feb. } 2016 \\
\text { Published: } 06 \text { June } 2016\end{array}$} \\
\hline \multicolumn{2}{|c|}{$\begin{array}{l}\text { How to cite this article: } \\
\text { Louw, S.W., Denton, R.A. \& } \\
\text { Grobler, H.B., 2016, "n } \\
\text { Praktykbenadering tot } \\
\text { geloofsvorming vanuit die } \\
\text { benadering van Thomas } \\
\text { Groome en die Gestaltteorie: } \\
\text { 'n Prakties-teologiese } \\
\text { dialoog', HTS Teologiese } \\
\text { Studies/Theological Studies } \\
\text { 72(3), a3197. http://dx.doi. } \\
\text { org/10.4102/hts.v72i3.3197 }\end{array}$} \\
\hline \multicolumn{2}{|c|}{$\begin{array}{l}\text { Copyright: } \\
\text { (C) 2016. The Authors. } \\
\text { Licensee: AOSIS. This work } \\
\text { is licensed under the } \\
\text { Creative Commons }\end{array}$} \\
\hline \multicolumn{2}{|c|}{ Attribution License. } \\
\hline \multicolumn{2}{|l|}{ Read online: } \\
\hline 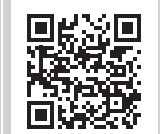 & $\begin{array}{l}\text { Scan this QR } \\
\text { code with your } \\
\text { smart phone or } \\
\text { mobile device } \\
\text { to read online. }\end{array}$ \\
\hline
\end{tabular}

The article describes the dialogue between Thomas Groome's approach to faith formation and Gestalt theory in order to develop a practice approach to faith formation. The transversal model of cross-disciplinary dialogue, developed by Wentzel van Huyssteen, is utilised to develop a practice approach to faith formation. The process of faith formation, according to Thomas Groome's Shared Christian Praxis approach, encompassing five movements, is described first. This is followed by a literature study on Gestalt theory. The philosophical roots of Gestalt theory as well as specific Gestalt concepts are explored in order to explain the process of human growth and change. Gestalt theory's paradoxical theory of change, as well as the contact cycle are utilised in order to explain the process of integration and assimilation of faith. The transversal dialogue is continued by relating the insights gained from Groome's approach and Gestalt theory. The context of missional ecclesiology, in which the researcher finds himself, is also accounted for during the dialogue. The process identifies six guidelines for the practice of faith formation. The findings of the dialogue are processed into a practice approach to faith formation. The practice approach is presented in such a way that it can be utilised in a variety of settings.

\section{Inleiding}

Daar is tans wydverspreide kommer oor die praktyk van geloofsvorming (Borgman 2006:435; De Wet 2003:1; Strommen \& Hardel 2008:16). Van der Merwe (2004:17) wys ook op die noodsaaklikheid van heil-sekerheid en heil-toeëiening op die weg na 'n gesonde spiritualiteit. Dean (2010:6) se navorsing fokus weer op wat sy die imposteur-geloof (imposter) noem, 'n geloof wat tekort skiet aan missionale helderheid en Christelike dissipelskap. Volgens Strommen en Hardel (2008:17) vind geloofsoordrag nie naastenby plaas soos wat veronderstel word nie.

In die Suid-Afrikaanse konteks het verskeie navorsers ook bydraes tot die veld gelewer (Du Toit 2007; Veldsman 2005). Dit blyk egter uit die bestaande navorsing dat daar nog nie 'n poging was om die benadering van Thomas Groome en die Gestaltteorie gesamentlik te ondersoek as moontlike bronne van kennis oor geloofsvorming nie. Phillip Brownell (2010:69) het waardevolle bydraes tot die integrasie van Gestaltterapie en die teologie gelewer. Op SuidAfrikaanse bodem is daar ook die werk van Denton (2010) wat binne 'n multidissiplinêre benadering op die tussenvlak tussen die pastoraat en Gestaltterapie werk. Vanuit gemelde bydraes is dit duidelik dat Gestaltteorie en die teologie die potensiaal het om as volwaardige gespreksgenote hanteer te word.

\section{Transdissiplinêre dialoog: 'n Transversale model}

Na aanleiding van die werk van Van Huyssteen $(1998,1999,2006)$ het ek vanuit'n postfondasionele ${ }^{1}$ benadering te werk gegaan. In Suid-Afrika het Müller (2004, 2005, 2009a, 2009b) reeds sinvolle bydraes in die teologie gelewer waarin hy die postfondasionele benadering as ' $n$ teoretiese raamwerk vir transdissiplinêre studie gebruik en ontwikkel het. ' $n$ Postfondasionele benadering maak 'n transversale model vir dialoog moontlik.

1.Sommige navorsers (vgl. Binneman 2010:40) vertaal die konsep in Afrikaans met "postfundamentalisties" Ek kies egter vir"n mee direkte vertaling, aangesien "postfundamentalisties" in Engels terugvertaal na "postfundamental", wat 'n ander konsep is.

Note: Dr Siegfried Louw is reverend of the Dutch Reformed Church Brackenfell Proteahoogte congregation. The article is an assimilation of the author's unpublished doctoral thesis under the supervision of Dr. R.A. Denton and Prof H.B. Grobler, with the title "n Praktykbenadering tot geloofsvorming vanuit die benadering van Thomas Groome en Gestaltteorie: 'n Prakties-teologiese dialoog' (Faculty of Theology, North-West University, Potchefstroom Campus, 2015). 
Osmer (2008:165-167; vgl. Denton 2014:8) noem dat daar drie modelle is waarvolgens interdissiplinêre dialoog tussen godsdiens en sielkunde kan plaasvind: korrelasionele modelle, transformasie-modelle en ' $n$ transversale model. Laasgenoemde is die mees onlangse model vir dialoog tussen die teologie en ander velde (Osmer 2008:170). Die transversale model vir transdissiplinêre dialoog is vir hierdie studie gebruik. Osmer (2008:170) beskryf die betekenis van transversaliteit as ... lying across, extending over, intersecting, meeting and converging without achieving coincidence.

Die transversale perspektief impliseer dat Groome se benadering en die Gestaltteorie nie geïntegreer word tot een nuwe teorie wat in alle omstandighede geldig moet wees nie. Die ontwikkeling van'n praktykbenadering tot geloofsvorming het gefokus op alle persone wat met die proses van geloofsvorming gemoeid is. Meer spesifiek was die fokus op die missionale konteks van die Nederduitse Gereformeerde kerk (NGK) waarvan ek 'n leraar is.

\section{Fase 1: 'n Beskrywing van die proses van geloofsvorming volgens Thomas Groome}

Thomas Groome is 'n wyd erkende praktiese teoloog wat 'n gevestigde kenner in die veld van geloofsvorming is (Beaudoin 2005:127; Browning 1988:84; O'Malley 2011:28; Schulte 2011:51; Walters 2004:208; Wong, McAlpine \& Buszowski 2009:306). Groome beklee tans 'n leerstoel in die Departement Godsdiensopvoeding en Pastorale Bediening aan die Boston-Kollege se teologiese skool. Groome (1999:57) beskou geloof as 'n geleefde realiteit met drie dimensies: (1) 'n geloofsoortuiging, wat meer spesifiek na geloofsinhoud verwys en intellektueel van aard is; (2) 'n aktiwiteit van vertroue wat meer affektief van aard is en (3) 'n wyse van leef wat meer konatief van aard is.

\section{Komponente van 'n gedeelde Christelike praksis}

Die komponente van Groome se benadering word vervolgens uiteengesit, waarna die vyf bewegings daarvan weergegee word.

\section{Huidige aksie}

Met 'huidige aksie' verwys Groome (1999:184) na die totale menslike betrokkenheid in die wêreld. Die wyse waarop die huidige aksie verwoord word, kan op verskillende maniere (vorme) plaasvind. Hierdie vorme kan insluit simbolisering, verbalisasie, skryf, uitbeelding of enige menslike uitdrukking. Groome (1999:185) fokus op deelnemers se persoonlike ervaring om te verhoed dat daar bloot in teorie opgegaan word.

\section{Kritiese refleksie}

Met kritiese refleksie verwys Groome (1999:185) na'n aktiwiteit wat vra na (1) kritiese denke om die hede te evalueer, (2) kritiese geheue sodat die verlede in die hede ontbloot kan word en, (3) kreatiewe verbeelding om die toekoms in die hede voor die gees te roep. Groome (1999:186) redeneer dat kritiese refleksie die gebruik van die rede, geheue asook persoonlike verbeelding moet betrek. Sodoende word die mens se eie geleefde deelname in die wêreld deel van die proses.

\section{Dialoog}

Groome (1999:189) spreek hom sterk daaroor uit dat die leeromgewing van geloofsvorming die Christelike gemeenskap is. Hy verwys na wat Martin Buber die 'I-Thou-verhouding' noem as die ideale konteks waarbinne hierdie dialoog kan plaasvind. Dialoog behels vir Groome om te vertel, asook om te luister. When dialogue involves authentic expressing/listening activity, then the consequences are both disclosure and discovery for the people involved (Groome 1999:189).

\section{Die 'storie'}

Groome gebruik die metafoor 'storie' as 'n groter en omvattender term as 'narratief': By Christian Story I mean the whole faith tradition of our people, however that is expressed or embodied (Groome 1999:192). Hy (Groome 1999:193) wys daarop dat God steeds aktief in die geskiedenis is en dat die mens voortdurend geroep word om te reageer op en deel te neem aan die 'storie'. Herinnering van die storie sluit in om te onthou hoe God in die mens se eie geloofsgemeenskappe gewerk het (Groome 1999:193).

\section{Die 'visie'}

Groome gebruik 'visie' om te verwys na sowel die geleefde reaksie waartoe die Christelike storie die mens uitnooi as die belofte wat God in die storie maak. Die storie is egter nog nie voltooi nie en die mens bevind sigself telkemale in nuwe historiese omstandighede, wat telkens na reaksie vra (Groome 1999:194). Die visie is ook kritiek op die huidige praksis en 'n maatstaf vir die wyse hoe die mens die storie uitleef.

\section{Teenswoordige dialektiese hermeneutiek}

Groome (1999:195) gebruik die term 'teenswoordige dialektiese hermeneutiek' (present dialectical hermeneutics) om te verwys na die hermeneutiese beginsel wat onderliggend aan 'n gedeeldepraksis-benadering is. Die taak van geloofsvorming behels vir Groome om mense te lei om God se wil vir hulle lewens te onderskei. Die dialektiese hermeneutiek word 'n oproep tot kreatiwiteit en getrouheid aan die uitnodiging van God, waar die huidige praksis storie se bydrae tot die visie as ewe belangrik geag word.

\section{Die vyf momente van 'n gedeelde Christelike praksis}

Die vyf momente van die gedeelde Christelike praksis van Groome se benadering word vervolgens uiteengesit.

\section{Eerste beweging: Verwoord die huidige aksie}

Die eerste beweging nooi deelnemers om hulle huidige aksie, sover dit die gekose onderwerp betref, te verwoord. Die fokus is nie teoretiese kennis nie, maar kennis wat in die deelnemers se praksis en persoonlike ervaring gegrond is (Groome 1999:210). 


\section{Tweede beweging: Deelnemers se stories en visies}

Tydens die tweede beweging word deelnemers bewus van hulle eie visies en stories soos wat dit in die huidige oomblik beleef word. Die tweede beweging wil onderskei wat die ooglopende van die huidige aksie is, maar ook bewustheid bevorder oor die bron of oorsprong wat daartoe aanleiding gegee het (Groome 1999:211).

\section{Derde beweging: Die Christelike gemeenskap se storie en visie}

Die derde beweging behels ' $n$ ontmoeting met die Christelike gemeenskap se storie. Dit sluit die visie in waartoe die storie die deelnemers uitnooi. Groome gebruik storie as 'n metafoor vir die geloofstradisie en visie as die geleefde reaksie en belofte waartoe hierdie geloofstradisie deelnemers uitnooi (Groome 1999:214). Die aanbieding van die storie en visie vind op 'n dialogiese wyse plaas sodat dit vir deelnemers ontsluit word.

\section{Vierde beweging: Dialektiese hermeneutiek tussen die 'Storie' en deelnemers se stories}

Deur middel van dialoog en dialektiek kan deelnemers die uitnodiging van die Christelike Storie en Visie in hul eie stories en visies toe-eien (Groome 1999:217). In werklikheid handel dit oor die vrae: 'Wat beteken die storie vir ons eie stories?' en 'Hoe respondeer ons stories met die storie? Twee sake moet egter in hierdie beweging gebeur: (1) Die geleefde geloofservaring word toegelig deur die Christelike geloofstradisie, en (2) die toe-eiening van die geloofstradisie vind binne die konteks van 'n geleefde geloof plaas (Groome 1999:218).

\section{Vyfde beweging: Dialektiese hermeneutiek tussen die 'Visie' en deelnemers se visies}

Die vyfde beweging veronderstel dat die tekens van die bewind van God, wat in die teenswoordige (hier en nou) reeds herken kan word, raakgesien word. In hierdie beweging word besluit hoe die reeds en die nog nie deelnemers uitnooi om 'n keuse uit te oefen vir' $n$ reaksie op die bewind van God (Groome 1999:221). Aangesien die Christelike geloof 'n wyse van wees in die wêreld veronderstel, is die vyfde beweging essensieel tot gedeelde Christelike praksis as benadering (Groome 1999:222).

\section{Die doelwit van geloofsvorming volgens Groome}

Die drie doelwitte van geloofsvorming vir die gedeelde Christelike praksis van Groome se benadering word vervolgens uiteengesit.

\section{Vir die bewind van God}

Groome (1998:14) beskou die bewind van God as die oorkoepelende doelwit van geloofsvorming. Groome (1998:14) verkies die term bewind (reign) bo koninkryk. Groome stel voor dat bewind van God gebruik word as 'n simbool vir die telos (einddoel) van die Christelike geloof. Binne God se verbondsverhouding met die mens behels die bewind van God dit wat God wíl: liefde en vryheid, vrede en geregtigheid, heelheid en volheid van lewe vir almal (Groome 1998:15).

\section{Vir geleefde Christelike geloof}

Naas die oorkoepelende doelwit van die 'bewind van God' behels die eerste onmiddellike eksistensiële doelwit van geloofsvorming die bevordering van 'n geleefde Christelike geloof in die lewens van mense. Indien mense as agentsubjekte van geloof beskou word, beteken dit dat geloof deur middel van kritiese kognisie hul eie gemaak behoort te word (Groome 1998:19). Die affektiewe/relasionele dimensie behels 'n vertroue in die mens se eie verhouding met God in Jesus, wat gevoed en gerealiseer word in verhouding met 'n Christelike geloofsgemeenskap vanwaar die verhouding met die hele mensdom beïnvloed word (Groome 1998:20). Die gedragsdimensie vra egter na die aktiwiteit om God se wil in die wêreld te doen (Groome 1998:21).

\section{Vir die heelheid van menslike vryheid}

Die heelheid van menslike vryheid is die tweede eksistensiële doel van geloofsvorming en behels die dryfkrag en gevolg van 'n geleefde Christelike geloof (Groome 1998:22). Vryheid sluit vir Groome al die waardes van God se bewind in.

\section{'n Teorie vir geloofsvorming in navolging van Aristoteles se 'drie lewens'}

Groome (1998:37) toon aan hoe daar deur die eeue verskil is oor die bron van betroubare kennis. Aan die een kant is daar die rasionalisme, waar die intellek die oorsprong van betroubare kennis is. Daarteenoor plaas Groome (1998:37) die empirisme, waarvolgens ervaring deur middel van sintuie die egte bron van idees is. Dit blyk dat Groome (1999:152-177) Aristoteles se 'drie vorme van leef' as basis gebruik om by sy gevolgtrekking uit te kom. Groome (1999:153) som Aristoteles se geïmpliseerde epistemologie soos volg op: Theoria is 'n wyse van soeke na kennis wat deur middel van ' $n$ kontemplatiewe of reflektiewe of onbetrokke proses plaasvind. Praxis is 'n soort kennis wat deur middel van reflektiewe betrokkenheid in 'n sosiale situasie ontwikkel. Dit behels 'n soort praktiese kennis wat op die vorming van menslike sosiale aksie gemik is. Poiesis is ' $n$ wyse van kennis wat deur middel van skeppendheid (om iets te maak) beliggaam word.

Groome (1998:46-47) verwerp die hiërargie wat Aristoteles aan die drie lewens heg, ook die trigotomie (drie-skeiding) tussen die drie lewens, asof hulle apart kan plaasvind. Daarenteen waardeer hy al drie lewens as geldige maniere om kennis te verkry. Hy waardeer asook Aristoteles se insluiting van die empiriese, sowel as die rasionele in die proses van weet omdat dit 'n terugroeping van wees (remembrance of being) reflekteer.

\section{Fase 2: Gestaltteoretiese perspektiewe op geloofsvorming}

In hierdie afdeling hanteer ek die volgende navorsingsvraag: Watter lig kan die Gestaltteorie op die proses van geloofsvorming werp? 


\section{Filosofiese wortels van die Gestaltteorie}

Crocker (2005:66) identifiseer die Gestaltteorie se belangrikste wortels as die psigoanalise van Freud, Horney, Rank en Reich; die holisme van Goldstein en die Gestaltsielkunde; Lewin se humanistiese ontwikkeling van veldteorie; pragmatiste soos Dewey en James; die filosofie van Aristoteles en Kant; die fenomenologie van Husserl; die eksistensialisme van Heidegger, Kierkegaard, Tillich en Buber; asook verskeie elemente vanuit die Chinese natuurfilosofie, Taoïsme en ZenBoedhisme.

\section{Fenomenologie}

Volgens Clarkson (2004:15) kan die fenomenologie, soos ontwikkel deur Husserl, Sartre en Merleau-Ponty, beskou word as dié filosofiese benadering wat in die hart van Gestalt lê. Die doel van Gestalt-fenomenologiese verkenning is bewustheid of insig (Yontef 1993:124). Joyce en Sills (2014:31) wys daarop dat die fenomenologiese benadering in Gestalt die mens altyd as ' $n$ aktiewe deelnemer beskou van dít wat ervaar word en hoé dit ervaar word. Vanuit' $n$ Gestalt-fenomenologiese perspektief is dit dus mense wat geloofswaarhede vir hulleself kan toe-eien.

\section{Dialogiese eksistensialisme}

Yontef (1993:126) wys op die verskil tussen Buber se 'I-Thou' en 'I-It' verhoudings. Volgens Yontef (1993:127) beklemtoon die Gestaltteorie vier eienskappe van dialoog om sodoende na 'I-Thou' kontak te streef: (1) Insluiting (inclusion) behels dat die self sover moontlik die veilige ruimte skep vir die ander om ook teenwoordig te wees sonder om te oordeel, te analiseer en te interpreteer. (2) Teenwoordigheid impliseer dat partye betrokke by geloofsvorming kies om in die hier-en-nou by mekaar teenwoordig te wees. (3) 'n Verbintenis tot dialoog beteken dat daar ' $n$ intensionele keuse gemaak word vir ' $n$ 'I-Thou' gerigtheid sodat waargeneem kan word wat tussen die 'ons' gebeur. (4) Laastens word dialoog geleef, eerder as om in teorie daaroor te praat (Yontef 1993:128). Die betekenis hiervan vir geloofsvorming is dat die totale manier van wees in mekaar se teenwoordigheid ' $n$ rol speel in die mate waartoe persone verantwoordelikheid vir hulle eie geloofsvorming aanvaar.

\section{Veldteorie}

Die veldteorie is een van die basiese teoretiese vertrekpunte van Gestaltterapie (Lobb \& Lichtenberg 2005:25; Yontef 1993: 125). Die veldteoretiese perspektief beskou die individu as deel van 'n groter geheel. Die self is dus nie 'n entiteit wat iewers binne-in die mens gevind kan word nie, maar die self ontluik in mense se interaksie met hulle veld (Joyce \& Sills 2014:135). Die veldteorie wys uit dat die toe-eiening van die Christelike storie en visie' $n$ funksie van geloofsvorming is wat die persoon self kan kies. Dit kan nie van buite geforseer word nie.

\section{Die paradoksale teorie van verandering}

Beisser $^{2}$ (1970:77) het die Gestalt-proses waarvolgens verandering plaasvind die paradoksale teorie van 2.Beisser (1970:77) se werk is die eerste bron waarin die term "paradoksale teorie van verandering' gebruik word. verandering genoem. Beisser (1970:77) beskryf die paradoksale teorie van verandering soos volg: ... change occurs when one becomes what he is, not when he tries to become what he is not. Die paradoksale teorie van verandering verklaar hoe verandering by mense kan plaasvind. Wanneer Groome (2011b:12-13) reken dat geloofsvorming 'n verandering van oortuigings, begrip, identiteit en persoonlike groei behels, voorsien die paradoksale teorie van verandering die raamwerk waarvolgens die verandering wat met geloofsvorming gepaard gaan, begryp kan word. Die paradoksale teorie van verandering wys uit dat dit kontraproduktief is om geloofsvorming op mense te probeer afdwing. Indien geloofsvorming deur middel van 'n sisteem aangedurf word wat wettiese reëls en voorskrifte voorhou as die norm wat bloot gehoorsaam en gevolg behoort te word, sal persoonlike verandering egter nie plaasvind nie.

\section{Baas/Klaas (Topdog/Underdog)}

Perls (Joyce \& Sills 2014:160) het graag gewerk met die digotomie tussen baas (topdog) en klaas (underdog). Perls (1969:18) beskou die baas as eiegeregtig en outoritêr - 'n boelie wat werk met 'jy moet' en 'jy mag nie'. Die klaas maak die teenoorstaande pool uit (Joyce \& Sills 2014:160) en probeer deur middel van passiwiteit beheer neem (Yontef 1993:78). Die klaas verteenwoordig die 'ek wil' aspek van persoonlikheid en verkry gewoonlik die oorhand oor die baas (Blom 2006:43). Sodoende ontstaan 'n dooiepunt (impasse) wat persone kan verhoed om elke nuwe situasie met die gepaste reaksie en kreatiwiteit te hanteer (Joyce \& Sills 2014:161).

Geloofsvorming het die potensiaal om op sodanige wyse plaas te vind dat dit 'n baas-klaas-spanning in die persoon se lewe bewerkstellig. Die geloofsinhoud kan die rol van ' $n$ baas in die persoon se lewe begin speel, wat tot ongesonde lewenspatrone in die wêreld kan lei. Die persoon se klaas kan die geloofsinhoud wat as baas funksioneer, ondermyn. Sodoende ontstaan 'n gefragmenteerde lewe, waarvan die geloofsaspek slegs in sekere fragmente van die persoon se lewe funksioneer.

\section{Introjeksie en assimilasie}

Indien eksterne standaarde outomaties deur mense aanvaar en ingeneem word, vind introjektering plaas (Yontef 1993:210). Joyce en Sills (2014) meld dat introjekte kan ontstaan wanneer idees met gesag afgedwing word:

Introjects are internalizations of others' beliefs, often significant societal rules that allow us to fit into our communities. Clear examples can be seen in forceful instructions given to children, which are absorbed often without understanding. (bl. 171-172)

Teenoor introjeksie behels assimilasie dat geloofsinhoud as deel van die persoon geïntegreer word. Indien geloofsinhoud geïntegreer en geassimileer word, is die implikasies dat 'n persoon die betrokke geloofsinhoud wel in verskillende uitdagings en lewensfases van toepassing sal kan maak en geloofsinhoud sal kan toeëien. 


\section{Organismiese selfregulering}

Die paradoksale teorie van verandering is gebaseer op 'n vertroue in die vermoë van die mens om op sodanige wyse te selfreguleer dat die toepaslikste aanpassing vir die konteks waarbinne geleef word, gemaak kan word (Yontef 2005:84). Vertroue in die organismiese selfregulering beteken dat ' $n$ persoon aanvaar word soos wat hy of sy in die huidige oomblik is (being) en dat daar ' $n$ bevestiging is van sy of haar inherente potensiaal om te groei (Yontef 1993:213). Gevolglik is daar slegs een doelwit in die organismiese selfregulering: bewustheid (Joyce \& Sills 2014:49; Philippson 2012:29; Truscott 2013:191; Yontef 2005:87). Bewustheid maak dit vir mense moontlik om verantwoordelikheid te aanvaar en om met bewuste keuses te besluit hoe hulle wil leef. Die implikasies van organismiese selfregulering op geloofsvorming is dat mense die geleentheid gegun behoort te word om aan die Christelike storie en visie blootgestel te word. Die organismiese selfregulering sal bepaal tot watter mate die persoon geïnformeer, geformeer en/of getransformeer word tot geloofsvorming.

\section{Die Gestalt-kontaksiklus}

Daar is ' $n$ verskeidenheid weergawes van en opinies oor die Gestalt-kontaksiklus. Joyce en Sills (2014:57) gebruik die term ervaringsiklus (cycle of experience) en meld dat ander benaminge soos bewustheidsiklus (cycle of awareness) of kontaksiklus (contact cycle) ook gebruik word. Die Gestaltkontaksiklus is 'n metafoor wat die vloei van bewustheid verduidelik (Joyce \& Sills 2014:57). Hierdie metafoor is handig in die opsig dat dit 'n eenvoudige manier is om die vorming, onderbreking of voltooiing van ontluikende figure te volg.

\section{Kontakmodifikasies}

Joyce en Sills (2014:148-158) verwys na verskeie kontakmodifikasies waarvolgens persone die kontaksiklus kan onderbreek:

- Samevloeiing: Yontef (1993:205) noem samevloeiing die afwesigheid van differensiasie tussen self en ander, asook 'n verlies aan eie identiteit.

- Introjeksie: Introjeksie vermy die oorweging van die toepaslikheid of geldigheid van ' $n$ bepaalde opinie. Joyce en Sills (2014:151) stel dit soos volg: The process of introjecting leads to holding beliefs that were not accepted choicefully-called introjects.

- Projeksie: Dit behels 'n proses van onteiening van 'n aspek van die self deur dit op iemand of iets anders te projekteer (Joyce \& Sills 2014:152-153).

- Defleksie: Defleksie is die wegkyk of wegdraai van 'n stimulus en dit word gekenmerk deur 'n uitblok van die stimulus self of deur 'n ander gedagtelyn te kies. So kan 'n persoon herhaaldelik die onderwerp verander wanneer 'n spesifieke kwessie aangeraak word of telkens verkeerd verstaan wat gesê word en dit herdefinieer (Joyce \& Sills 2014:154).

- Retrofleksie: Retrofleksie vind plaas wanneer 'n persoon 'n impuls om aksie te neem (bv. om te praat of uitdrukking aan emosie te gee) onderdruk. Die energievloei word op hierdie manier onderdruk (Joyce \& Sills 2014:156).

- Desensitasie: Desensitasie is ' $n$ baie sterker vorm van afsluiting as defleksie. Enige bewustheid oor 'n spesifieke saak gaan verlore (Joyce \& Sills 2014:156).

- Selfmonitering: Gesonde selfmonitering is die vermoë tot selfrefleksie en refleksiwiteit. Gewoontevormende en beperkende selfmonitering word gekenmerk deur oormatige selfkritiek wat spontaneïteit en volle kontak ondermyn (Joyce \& Sills 2014:148).

- Impulsiwiteit: Impulsiwiteit is ' $\mathrm{n}$ vorm van aksie sonder genoegsame oorweging van die konteks of die gevolge van die aksie. Joyce en Sills (2014:158) beskryf impulsiwiteit soos volg: In terms of the cycle of experience, this client moves straight to action before fully recognizing and evaluating the emerging sensations.

Kontakmodifikasies voorsien 'n moontlike verklaring waarom integrasie van geloof nie by mense plaasvind nie, aangesien so 'n onderbreking in die kontaksiklus integrasie blokkeer.

\section{Fase 3: Identifisering van trajekte vir geloofsvorming binne die konteks van 'n missionale ekklesiologie}

Tydens die derde fase van die navorsing het die kulminasie van die transversale dialoog plaasgevind. Vir die doeleindes van hierdie studie het ek gekies om die missionale ekklesiologie wat die NGK by die Algemene Sinode van 2013 as amptelike ekklesiologie aanvaar het (NGK 2013:8), te gebruik as vertrekpunt vir die konteks waarbinne die transversale dialoog plaasvind.

\section{Missionale ekklesiologie as huidige bedieningskonteks}

Die gesprekke wat tans oor die missionale aard en roeping van die kerk in die NGK aan die gang is, word gevoer vanuit die boustene van die Reformasie (Niemandt \& Meiring 2013:3). Die eerste bousteen behels die vier 'solas', wat as reaksies teenoor ander standpunte gehuldig is: sola scriptura, solus Christus, sola gratia en sola fide. ' $n$ Tweede bousteen van die Reformasie behels die openheid en gewilligheid om telkens weer nuut te dink en voortdurend te hervorm (semper reformanda) (Niemandt \& Meiring 2013:3).

'n Missionale ekklesiologie word geskoei op die wyse hoe God as Drie-Enige God verstaan word. In die Bybel word God as één beskou, maar die mens leer God in drie persone ken: Vader, Seun en Heilige Gees (Niemandt \& Meiring 2013:3).

\section{Die kerk se missie is ingebed in God se missie}

Die Drie-Enige God stuur die kerk die wêreld in (Matt 28:1820) as deel van God se sending (Niemandt \& Meiring 2013:4), want God is in wese 'n sturende God. Niemandt en Meiring (2013:3) stel dat God alles skep en onderhou '... met die oog op 'n eindbestemming (eskaton): die koninkryk van God, 'n innige verbondsverhouding, 'n nuwe, verheerlikte hemel en aarde waarin God alles in almal sal wees'. 
Christus se vleeswording speel 'n groot rol in 'n missionale ekklesiologie en roep die kerk op om 'n inkarnasie-leefstyl na te streef (Joh 17:18-20; Niemandt \& Meiring 2013:7). Met Jesus se menswording word die voorbeeld vir menslikheid en medemenslikheid gestel. Inkarnasie en die navolging van Christus bring die kwesbaarheid van die kerk ter sprake. Saam met die konsep van Christus se inkarnasie is die kenosis as konsep ook ter sprake. Kenosis (Niemandt \& Meiring 2013:7) word deel van die manier hoe die kerk bestaan en behels selfprysgawe en opoffering (vgl. Fil 2:5-11).

\section{Missionale geloofsvorming}

Missionale geloofsvorming hef die dualisme tussen 'n geestelike lewe en 'n gewone lewe op. Niemandt en Meiring (2013:10-11) stel dat missionale spiritualiteit 'n bewussyn van God se lewende teenwoordigheid is. Die geloofsvorming (bewussyn) gee betekenis aan ' $n$ mens se lewe en stimuleer, motiveer en gee aan gelowiges lewenskrag op die pad waarop die Here mense stuur.

\section{Missionale rigtingwysers vir geloofsvorming}

Die volgende rigtingwysers vir geloofsvorming is vanuit die missionale ekklesiologie geïdentifiseer.

\section{Neem deel aan die koninkryk van God}

'n Missionale ekklesiologie roep gelowiges op om deel te neem aan dít waarmee God besig is. Geloofsvorming het ten doel om gemeenskappe te begelei sodat hulle intensioneel deelneem aan die koninkryk van God.

\section{Erken lidmate, veral jongmense, as gidse}

Geloofsvorming behoort die rol van jongmense as gidse op die geloofsreis baie duidelik te ondersteun (Niemandt \& Meiring 2013:14). Geloofsvorming is dus afhanklik van die persone wat tradisioneel as subjekte van geloofsvorming beskou is.

\section{'n Geïntegreerde spiritualiteit}

Daar is nie meer ruimte vir ' $n$ dualistiese lewensbeskouing waarvolgens daar 'n geestelike lewe en 'n sekulêre of gewone lewe bestaan nie. Geloofsvorming het dit ten doel om gelowiges te help om op alle lewensterreine aan die koms van die koninkryk deel te neem.

\section{Wees teenwoordig en luister}

Indien geglo word dat God in alle lewenskontekste teenwoordig is en dat geloofsvorming dit dan ten doel het om mense te help om dit te herken, vra dit van gelowiges om intensioneel in hulle omstandighede teenwoordig te wees. Deur op te daag in die lewe, teenwoordig te wees en oop te wees om te luister, word die koms van God se koninkryk raakgesien. Geloofsvormingsprosesse behoort gelowiges te nooi om werklik teenwoordig te wees in die wêreld aangesien dit deel vorm van Christus se inkarnasie in die wêreld.

\section{Ervaring is belangrik}

Zscheile (2012:23) se siening dat missionale Christelike vorming 'n houding van verwondering kweek, werp verdere lig op die idee dat gelowiges se belewenis van die wêreld ' $n$ belangrike bron vir geloofsvorming is. Die implikasies vir geloofsvorming behels dat dit 'n proses behoort te wees waarvolgens geloof geleef moet word. Dít wat in die lewenswerklikheid beleef word, is die einste konteks wat deur die kerk bely kan word as die wêreld waarin God se koninkryk besig is om te kom.

\section{Onderskeiding is die sleutel}

Geloofsvorming behoort só plaas te vind dat mense gehelp en geleer word om onderskeidend te kan leef en leer. Niemandt en Meiring (2013:10) beskou onderskeiding as die hart van geloofsvorming binne 'n missionale konteks.

\section{Gee mag weg}

Die inkarnasie van Jesus Christus en sy selfprysgawe vra dat persone wat by prosesse van geloofsvorming betrokke is, bereid sal wees om te dien. Geloofsvorming word nie vanuit'n posisie van mag gedoen nie.

\section{Ontsluiting van die Bybel en die geloofstorie}

'n Missionale ekklesiologie verg dat geloofsvorming só geskied dat dit die krag van die evangelie in die Bybel vir mense ontsluit (vgl. Keifert 2007:114). Toeganklikheid tot die geloofstorie soos wat dit in die Bybel aangetref word, is 'n vereiste sodat mense dit kan toe-eien binne hul eie lewensituasie en hulle in staat gestel word om deel te neem aan dít waarmee God besig is.

\section{Missionale geloofsvorming is nooit afgehandel nie}

Indien geloofsvorming verstaan word as 'n proses wat mense leer hoe om te onderskei op watter wyse God binne die huidige kontekste (hier en nou) in die wêreld aan die werk is, dien dit te verstane dat dit 'n voortgaande proses is.

\section{Rigtingwysers vir geloofsvorming vanuit Groome se benadering}

Die volgende rigtingwysers vir geloofsvorming is vanuit Groome se benadering geïdentifiseer.

\section{Vir die bewind van God}

Groome (2011a:8) stel dat die kerk ter wille van die bewind van God met geloofsvorming besig is. As die intensie veronderstel is om lewegewend en emansipatories van aard vir alle gemeenskappe te wees, dui Groome (2011b:90) aan dat blote gedragsmodifikasie of doktrinêre oordrag nie gepas is nie.

\section{Gee oorheersende mag weg}

Mense wat by geloofsvorming betrokke is, is agent-subjekte. Dit is ' $n$ bemagtigende benadering wat die grond tussen leerders en opvoeders gelyk maak (Groome 2011b:90). Mag moet eerder saam met ander as oor ander wees (vgl. Groome 1999:16). 


\section{Erken ervaring}

Groome (2011b:111) eis dat geloofsvorming plaasvind op sodanige wyse dat verstand, hart en hande daarby betrek word. Wanneer Groome (2011b:275) verwys na sy benadering as 'n vloei van life to Faith to life, stel hy dit duidelik dat hierdie lewe (life) die volle lewe behels.

\section{'n Openheid om aktief te luister}

Groome se benadering (vgl. Beaudoin 2005:134) nooi mense om te herken hoe die bewind van God in die hier en nou na hulle toe kom. Dit verg 'n openheid om te hoor hoe mense God se bewind in hulle lewens ervaar, asook hoe die Christelike storie en visie dit transformeer.

\section{Maak erns met die geloofstorie en die Bybel}

Die Christelike storie en visie is as't ware die spilpunt van Groome se proses. Die hoofdoel van die aanbieding van die Christelike storie en visie is om mense te bemagtig om 'n ontmoeting (encounter) te hê met die breër storie en visie soos wat dit uit die Christelike geloofstradisie na vore kom (Groome 1999:217).

\section{Onderskeiding is noodsaaklik}

Groome (2011b:117) argumenteer dat die Christelike geloof 'n wyse van onderskeiding en besluitneming verg. Onderskeiding is 'n wyse hoe God se teenwoordigheid in mense se alledaagse lewens geëer en respekteer word (Groome 2011b:285).

\section{Maak ruimte vir alternatiewe}

Transformasie beteken dat identiteit, wil en handel vernuwe word. Groome se benadering vereis dat geloofsvorming só behoort te gebeur dat mense oop is vir alternatiewe wyses van leef.

\section{Neem deel aan die bewind van God}

Geloofsvorming behoort mense te betrek om met verantwoordelikheid te reageer (Groome 2011b:122).

\section{Skep ruimte vir intensionele kreatiwiteit}

'n Kreatiewe uitdrukking van mense se eie storie en visie is noodsaaklik (Groome 1999:208). Die Bybel en die res van die Christelike storie en visie behoort ook duidelik en kreatief gekommunikeer te word. Om die Christelike storie en visie toe te eien en op mense se lewens van toepassing te maak, verg kreatiewe verbeelding.

\section{Geloofsvorming behoort 'n lewenslange proses te wees}

Groome (2011b:52) argumenteer dat geloofsvorming 'n lewenslange proses is. Die Christelike storie en visie is steeds besig om verder te ontvou.

\section{Rigtingwysers vir geloofsvorming vanuit die Gestaltteorie}

Die volgende rigtingwysers vir geloofsvorming is vanuit die Gestaltteorie geïdentifiseer.

\section{Die verhouding is essensieel}

Die dialogiese verhouding in die Gestaltteorie voorsien 'n duidelike rigtingwyser vir geloofsvorming: Dit behoort só te geskied dat mense tot eerlike dialoog genooi word. Die Gestaltteorie dui aan dat mense die behoefte het aan 'n ruimte waarbinne hulle bemagtig word om keuses uit te oefen vir nuwe moontlikhede - teenoor 'n lewenshouding wat bloot probeer navolg wat van die self verwag word.

\section{Neem mense se kontak met hulle lewenswêreld ernstig op}

Persone is nie bloot in die veld (lewenswêreld) nie, maar is self aspekte (deel) van die veld (Joyce \& Sills 2014:200). Enige proses van geloofsvorming kan daarom nie anders as om mense se lewenswêrelde ernstig op te neem nie.

\section{Ervaring en belewenis is belangrik}

In die Gestaltteorie is mense se eie ervaring en belewenis essensieel. Prosesse van geloofsvorming behoort erkenning te gee aan die ervarings en belewenisse van mense en behoort dit te ontgin.

\section{Wees teenwoordig in die hier en nou}

Geloofsvormingsprosesse behoort mense te help om gefokus te bly in die hier en nou, selfs al word daar oor die verlede en die toekoms gepraat.

\section{Mag is saam met ander}

Die Gestaltteorie wys dat een mens nie 'n ander mens vorm nie. Geloofsvorming wat vanuit 'n posisie van mag oor ander benader word, het 'n groter waarskynlikheid om tot introjeksie te lei, asook tot 'n baas-klaas-spanning by die persoon (vgl. Yontef 1993:211).

\section{Aanvaar mense se verantwoordelikheid}

Organismiese selfregulering illustreer mense se vermoë en natuurlike prosesse om te kies en betekenis te verskaf (Yontef \& Jacobs 2014:300). Elke mens is vir sy of haar selfregulering verantwoordelik.

\section{Skep ruimte vir alternatiewe}

Verantwoordelikheid het die implikasie dat mense keuses kan uitoefen en die verantwoordelikheid vir die gevolge van die keuse kan aanvaar (Yontef 1993:141). Geloofsvormingsprosesse behoort aan mense voldoende geleentheid te gee om te besin oor alternatiewe interpretasies van konsepte en ervarings of oor alternatiewe maniere van wees en optree.

\section{Bewustheid is die sleutel}

Die doelwit van Gestaltterapie is om mense tot bewustheid te begelei (Joyce \& Sills 2014:49; Philippson 2012:29; Truscott 2013:191; Yontef 1993:12, 2005:87). Enige kennis wat mense deur middel van geloofsvorming opdoen, behoort langs die weg van bewustheid in hulle eie lewe geïntegreer te word. 


\section{Assimilasie en integrasie is die mikpunt}

Indien inhoud tydens prosesse van geloofsvorming só aangebied word dat die inhoud deur middel van assimilasie deel word van mense se self, bly dit nie 'n vreemde (foreign) objek apart van die self nie (vgl. Yontef 1993:179).

\section{Erken die kontaksiklus}

Daar behoort voorsiening gemaak te word vir verskillende tipes kontaksiklusse. Met sommige prosesse sal 'n korter siklus meer effektief wees om voltooidheid te verkry, terwyl ander prosesse weens die kompleksiteit daarvan oor ' $n$ langer tydperk moet plaasvind.

\section{Akkommodeer kontakgrensmodifikasies}

Kontakgrensmodifikasies kan gesonde of gepaste reaksies binne bepaalde omstandighede wees (Joyce \& Sills 2014:159). Die belang vir geloofsvorming is egter dat voortdurende of gereelde kontakgrensmodifikasies integrasie kan verhoed of bemoeilik. Dit is dus nodig dat kontakgrensmodifikasies erken en herken behoort te word, sodat die vloei van kontak herstel kan word.

\section{Wees kreatief}

Aangesien die doelwit in die Gestaltteorie bewustheid is, beteken dit dat verskillende kreatiewe aktiwiteite ingespan kan word om mense te help om te identifiseer waarvan hulle bewus word. Tydens prosesse van geloofsvorming behoort kreatiewe oefeninge deel van die prosesse te wees om mense in hulle bewuswordingsproses te help.

\section{Geloofsvorming behoort lewenslank te gebeur}

Die selfregulerende organisme illustreer dat die mens voortdurend besig is om na balans (ekwilibrium) te streef. Soos wat nuwe uitdagings en lewensfases aanbreek, ontstaan die behoefte om te herinterpreteer en weereens, op 'n nuwe manier, geloofsinhoud op sodanige wyse toe te eien dat dit sin maak binne veranderde omstandighede.

\section{Riglyne vir geloofsvorming}

Vervolgens word ses riglyne vir geloofsvorming geïdentifiseer. Die riglyne behels die samevoeging van trajekte wat vanuit die Gestaltteorie en Groome se benadering in dieselfde rigting dui wanneer geloofsvorming binne die konteks van 'n missionale ekklesiologie ter sprake is.

\section{Vir die bewind van God}

'n Missionale ekklesiologie asook Groome se benadering beklemtoon die bewind van God as doelwit vir geloofsvorming. In die Gestaltteorie is die doelwit bewustheid, maar op sodanige wyse dat 'n fragmentering tussen die gewone lewe en 'n spirituele lewe duidelik nie volhoubaar is nie. Die Gestaltteorie verleen verdere insig in die feit dat integrasie van houdings, emosies en gedagtes 'n direkte invloed op die optrede van die persoon het.

\section{Ontmoetings met die Christelike storie}

Groome se benadering plaas die Christelike storie en visie in die sentrum. Kontak as 'n Gestalt-konsep wys die belangrikheid uit dat indien enige storie oor of visie van geloof ter sprake kom, werklike kontak met die storie of visie noodsaaklik is vir integrasie. Die Gestaltteorie vestig die aandag op verskillende eksperimente wat gedoen kan word om mense te begelei om te ervaar wat met hulle gebeur wanneer hulle met hul sintuie die storie of visie beleef. 'n Missionale ekklesiologie het ook die belang van die Christelike storie uitgewys.

Kontakgrensmodifikasies identifiseer die wyse waarop mense se kontak met die Christelike storie of visie belemmer kan word. Groome maak nie hiervoor voorsiening nie. In hierdie opsig lewer die Gestaltteorie 'n baie waardevolle bydrae om in die praktyk van geloofsvorming te verreken.

\section{Onderskeidende wysheid}

Missionale geloofsvorming, Groome se benadering en die Gestaltteorie gaan voortdurend op 'n onderskeidende wyse te werk om sin te gee aan gebeure, lewensomstandighede, ervarings, gedagtes en emosies. 'n Spesifieke bydrae wat vanuit die Gestaltteorie na vore tree, is die fokus op die hier en nou tydens die onderskeidingsproses. Terwyl Groome die noodsaaklikheid van drie verskillende soorte kennis aandui (poiesis, praksis en theoria), blyk dit dat die Gestaltteorie aantoon hoe hierdie verskillende soorte kennis verkry kan word: deur in die hier en nou teenwoordig te wees en daaruit deel te neem aan die proses.

\section{Selfopofferende verhoudings}

Vir Philippson (2012:64-65) as verteenwoordiger van die Gestaltteorie, vir Groome (1999:17), asook vir Osmer (2012:50), wat oor vorming in die missionale kerk skryf, lê die funksie van mag daarin dat mag verwys na solidariteit in die teenwoordigheid van ander gelowiges. Ek kies daarom die term selfopoffering as verwysende na die solidariteit met ander.

\section{Waarderende openheid}

Vanuit die missionale ekklesiologie is die volgende rigtingwysers geïdentifiseer:

- Erken lidmate, veral jongmense, as gidse.

- Lewe met 'n geïntegreerde spiritualiteit.

- Ervaring is belangrik.

- Missionale geloofsvorming is nooit afgehandel nie.

- Vanuit Groome se benadering is die volgende rigtingwysers geïdentifiseer wat met waarderende openheid in verband gebring kan word:

- Erken ervaring.

- Luister aktief met openheid.

- Geloofsvorming behoort 'n lewenslange proses te wees.

Vanuit die Gestaltteorie dui die volgende rigtingwysers op 'n waarderende openheid:

- Neem mense se kontak met hulle lewenswêreld ernstig op. 
- Ervaring en belewenis is belangrik.

- Geloofsvorming behoort lewenslank te gebeur.

Wanneer hierdie onderskeie rigtingwysers almal langs mekaar geplaas word, word 'n trajek wat 'n houding van waarderende openheid suggereer, duidelik sigbaar.

\section{Uitnodiging tot kreatiwiteit}

Die Gestaltteorie toon aan dat 'n uitnodiging tot kreatiwiteit bemagtigend is vir bewustheid. In Groome se benadering is kreatiewe uitdrukking as sleutelrol uitgewys. Vanuit die missionale ekklesiologie is daar nie 'n duidelike rigtingwyser geïdentifiseer wat kreatiwiteit aanmoedig nie, behalwe dat die ervaring en belewenisse van mense belangrik is.

\section{Fase 4: 'n Praktykbenadering tot geloofsvorming}

Vir die praktykbenadering word die riglyne as oop-einde riglyne hanteer wat in die praktyk binne 'n verskeidenheid van kontekste toegepas kan word.

\section{Die doelwit van geloofsvorming: Vir die bewind van God}

Die einddoel van geloofsvorming is die bewind van God. Die bewind van God behoort as 'n aaneenlopende proses beskou te word wat ook in die verlede en hede herkenbaar is. Geloofsvorming wat vir die bewind van God plaasvind, hef die dualisme tussen 'n geestelike lewe en 'n gewone lewe op. 'n Missionaleekklesiologiefunksioneervanuitdiegeloofsoogpunt dat God in die wêreld besig is. God se bewind bring volgens Groome vryheid vir alle mense, asook die wêreld. Dit beteken dat die proses van geloofsvorming só benader word dat dit mense help om raak te sien waar en hoe God in hulle lewens en omgewing besig is, op sodanige wyse dat dit hulle bemagtig om deel te neem aan die bewind van God.

\section{Die spilpunt van geloofsvorming: Ontmoetings met die Christelike storie}

In Groome se benadering van lewe na geloof na lewe lê die heraanbieding van die Christelike storie en visie in die sentrum van die proses. Die navorser gebruik die term storie as inklusief sodat die betekenis van visie ook daarin vervat word. Buiten die breër Christelike storie lê die klem in die Gereformeerde tradisie op die Woord self. In terme van Groome se benadering behoort dit al drie vorme van kennis (theoria, praxis en poiesis) te betrek. In terme van die Gestaltteorie behoort kontak gemaak te word met die Christelike storie. Hoe meer die sintuie, emosies, denke en dade by die ontmoeting met die Christelike storie betrek word, hoe beter is dit vir die proses van geloofsvorming (vgl. Joyce \& Sills 2014:57-58; Kepner 2013:120-121; Woldt \& Toman 2005:x-xi).

\section{Onderskeidende wysheid}

Onderskeiding en bewustheid vind in die hier en nou plaas. Die implikasies is dat deelnemers die geleentheid gegun moet word om in die hier en nou te kan onderskei watter reaksies, emosies, houdings, gedagtes en ook liggaamlike sensasies die proses van die ontmoeting met die Christelike storie by hulle ontlok. Die doelwit, vir die bewind van God, is 'n konstante herinnering dat God in die hier en nou ook teenwoordig en besig is.

\section{Selfopofferende verhoudings}

Selfopofferende verhoudings fokus op die gemeenskap wat saam, in 'n veilige ruimte, die geloofsvormingsproses laat plaasvind binne die missionale ekklesiologie wat in die DrieEenheid gewortel is. Dit is deur middel van 'n dialogiese verhouding wat 'n derde spasie saam deur die betrokke partye geskep word.

Groome (1999:226) beskryf die omgewing waarbinne refleksie plaasvind as 'n omgewing van vertroue, gasvryheid, warmte en openheid. Hiervolgens behoort jongmense egter as geloofsvormingsgidse erken te word. Die navorser reken dat hierdie stap slegs moontlik is in 'n omgewing waarbinne fasiliteerders bereid is om, in solidariteit met ander, van hulleself weg te gee sodat daar 'n bereidwilligheid is om self ook te leer, gevorm en verander te word.

\section{Waarderende openheid}

Groome se fokus op die mens wat na die beeld van God geskape is, speel veral 'n groot rol in sy teologiese antropologie. Terselfdertyd assosieer Groome die teologiese konsep van beeld van God met vryheid (Groome 1999:82-99), wat hy dan ook koppel aan die doelwit van geloofsvorming (wat in hierdie praktykbenadering omskryf word deur die term bewind van God). Die Gestaltteorie is egter sterk deur die fenomenologie beïnvloed. Drie beginsels van die fenomenologie toon aan hoe waarderende openheid in die praktyk toegepas kan word:

- Pas die reël van epoché (bracketing) toe.

- Gee 'n beskrywing van die fenomeen volgens die onmiddellike en konkrete indrukke daarvan.

- Vermy dit om te bepaal watter beskrywings van ervarings belangriker is as ander.

Saam met die openheid gaan die proses van geloofsvorming met nie-veroordeling en ' $n$ verwelkomende gesindheid gepaard.

\section{Kreatiwiteit}

Kreatiwiteit is die modus waarvolgens die proses van geloofsvorming plaasvind. Daar is twee sake wat pertinent na vore tree:

- die geleentheid om deur middel van kreatiewe uitdrukking mense te bemagtig om hulle eie storie en visie na vore te bring

- die geleentheid om saam kreatief te kan wees in die skepping van 'n alternatiewe werklikheid waarin die lewe anders geleef kan word. 
Groome (1998) beskryf die benutting van kreatiwiteit in sy Gedeelde Christelike Praksis soos volg:

The 'creative' dimension is honored by attending to people's historical visions and to the Vision of God's reign by enlivening their imaginations and empowering their wills to be cocreators of it now. (bl. 48)

Hierdie Gestaltteoretiese perspektiewe op kreatiwiteit is hierbo uitgelig. Joyce en Sills (2014:130) verskaf konkrete voorstelle oor moontlike opsies om bewustheid te bevorder: visualiseringsoefeninge, verskeie kunsmateriale, musiek, sang, dans, foto's en skryfwerk. Uiteindelik is die veronderstelling dat bewustheid sal lei tot kreatiewe aanpassing in die lewe om ontmoetings met die Christelike storie in die proses van geloofsvorming te laat realiseer.

\section{Samevatting}

In hierdie studie is ' $n$ transversale dialoog tussen Groome se benadering en dieGestaltteorie ontgin om'n praktykbenadering tot geloofsvorming binne die konteks van 'n missionale ekklesiologie te genereer. Die rigtingwysers vir geloofsvorming wat vanuit die Gestaltteorie en Groome se benadering asook vanuit 'n missionale ekklesiologie geïdentifiseer is, is in die transversale dialoog by mekaar uitgebring om riglyne te identifiseer vir die praktykbenadering tot geloofsvorming.

Die dialoog tussen Groome se benadering en die Gestaltteorie het 'n unieke bydrae oor die praktyk van geloofsvorming gelewer. Indien die ses riglyne wat in die praktykbenadering tot geloofsvorming opgeneem is, toegepas word, behoort dit ook binne die Suid-Afrikaanse konteks van groot waarde te wees:

1. Geloofsvorming wat plaasvind vir die bewind van God sal mense kan help om te begryp dat geloofsvorming nie bloot van elke individu plaasvind nie. Geloofsvorming vind plaas ter wille van die wêreld en alle mense, wat deel is van God se bewind.

2. Ontmoetings met die Christelike storie, as riglyn, behoort Christelike gemeenskappe te help om te fokus op byeenkomste en prosesse waarvolgens elke persoon die geleentheid gegun word om persoonlik te beleef watter impak die Christelike storie op hom of haar het.

3. Die ander vier riglyne is steeds gefokus op ontmoetings met die Christelike storie en gee 'n duidelike beeld van die wyse waarop mense in mekaar se teenwoordigheid behoort op te tree om ontmoetings met die Christelike storie saam te kan beleef. Dit is 'n bemagtigende praktykbenadering wat ten diepste daarop gemik is om geloofsgemeenskappe te begelei om hulle leefwêreld te transformeer.

\section{Erkenning \\ Mededingende belange}

The authors declare that they have no financial or personal relationships which may have inappropriately influenced them in writing this article.

\section{Outeursbydrae}

S.L. is 'n leraar in die Nederduitse Gereformeerde Kerk Brackenfell, Proteahoogte. Hy het sy PhD voltooi in 2015. Hierdie artikel is 'n assimilasie van die outeur se ongepubliseerde doktorale proefskrif onder leiding van R.A.D. en H.B.G., met die titel "n Praktykbenadering tot geloofsvorming vanuit die benadering van Thomas Groome en Gestaltteorie: 'n Prakties-teologiese dialoog' (Fakulteit Teologie, Noordwes Universiteit, Potchefstroom).

\section{Literatuurverwysings}

Beaudoin, P., 2005, 'The theological anthropology of Thomas Groome', Religious Education 100(2), 127-138, viewed 6 August 2010, from http://www.tandfonline. com/doi/abs/10.1080/00344080590932427\#.VCEcvfmSySo

Beisser, A., 1970, 'The paradoxical theory of change', in J. Fagan \& I. Shepherd (eds.), Gestalt therapy now: Theory, techniques, applications, pp. 77-80, Science and Behavior Books, Palo Alto, viewed 30 August 2014, from http://www.gestalt.org/ arnie.htm

Binneman, A.J., 2010, 'Identiteit en homoseksualiteit: Die soeke na aanvaarding binne 'n Christelike geloofsgemeenskap', PhD-proefskrif, Departement Praktiese Teologie, Universiteit van Pretoria, besigtig op 11 Februarie 2012, by http://upetd. up.ac.za/thesis/available/etd-05192011-115529/

Blom, R., 2006, The handbook of gestalt play therapy: Practical guidelines for child therapists, Jessica Kingsley Publishers, London.

Borgman, D., 2006, 'Bridging the gap: From Social science to congregations, researchers to practitioners', in E.C. Roehlkepartain, P.L. Benson, P.E. King \& L.M Wagener (eds.), The handbook of spiritual development in childhood and adolescence, pp. 435-444, Sage, Thousand Oaks.

Brownell, P., 2010, Gestalt therapy: A guide to contemporary practise, Springer Publishing Company, New York.

Browning, D., 1988, 'Reading recommendations: Practical theology', Theological Education 25(1), 83-85, viewed 3 June 2012, from ATLA Religion Database with ATLASerials, EBSCOhost.

Clarkson, P., 2004, Gestalt counseling in action, Sage, London.

Crocker, S.F., 2005, 'Phenomenology, existentialism, and Eastern thought in gestalt therapy', in A.L. Woldt \& S.M. Toman (eds.), Gestalt therapy: History, theory and practice, pp. 65-80, Sage, London.

Dean, K.C., 2010, Almost Christian: What the faith of our teenagers is telling the American church, Oxford University Press, New York.

Denton, R.A., 2010, 'Pastorale Gestaltterapeutiese intervensie om mishandelde laatadolessente wat skuld en skaamte ervaar, na vergifnis te begelei', PhD-proefskrif, Departement Filosofie, Praktiese en Sistematiese Teologie, Universiteit van SuidAfrika.

Denton, R.A., 2014, 'Exploring Biblical Reformational theology as a normative perspective for Christian psychology', In Die Skriflig/In Luce Verbi 48(1), 11 pages. http://dx.doi.org/10.4102/ids.v48i1.1791

De Wet, D.C., 2003, "n Gemeenskapsgerigte model vir geloofsvorming van tieners in die verbondsgesin deur middel van simbole en rituele', PhD-proefskrif, Departement Praktiese Teologie, Universiteit van Pretoria.

Du Toit, D., 2007, 'Die rol van die verbondsouers en die kerk in die aanspreek van die geloofsvormingskrisis van adolessente', MDiv-verhandeling, Departement Praktiese Teologie, Universiteit Stellenbosch, Stellenbosch.

Groome, T.H., 1998, Sharing faith: A comprehensive approach to religious education and pastoral ministry, Wipf \& Stock, Eugene.

Groome, T.H., 1999, Christian religious education: Sharing our story and vision, JosseyBass, San Francisco.

Groome, T.H., 2011a, 'From life to faith to life: Some traces', Journal of Adult Theological Education 8(1), 8-23, viewed 9 January 2014, from http://dx.doi. org/10.1558/JATE.v8i1.8

Groome, T.H., 2011b, Will there be faith?: A new vision for educating and growing disciples, HarperCollins, New York.

Joyce, P. \& Sills, C., 2014, Skills in Gestalt counselling and therapy, Sage, London.

Keifert, P.R., 2007, Ons is nou hier: 'n Nuwe era van gestuur-wees, Bybelmedia, Wellington.

Kepner, J.I., 2013, Body process: Working with the body in psychotherapy, Routledge, New York.

Lobb, M.S. \& Lichtenberg, P., 2005, 'Classical Gestalt therapy', in A.L. Woldt \& S.M. Toman (eds.), Gestalt therapy: History, theory and practice, pp. 21-39, Sage, London.

Müller, J., 2004, 'HIV/AIDS, narrative practical theology, and postfoundationalism: The emergence of a new story', Hervormde Teologiese Studies 60(1/2), 293-306. 
Müller, J., 2005, 'A postfoundationalist, HIV-positive practical theology', Practical Theology in South Africa 20(2), 72-88.

Müller, J., 2009a, 'Holistic pastoral ministry in a time of transition', paper presented at the Joint Conference of Academic Societies in the fields of religion and theology, University of Stellenbosch, 23 June 2009, viewed 2 March 2010, from http://www.julianmuller.co.za

Müller, J., 2009b, 'Transversal rationality as a practical way of doing interdisciplinary work, with HIV and Aids as a case study', paper presented at the Seventh International Conference on New Directions in the Humanities, 2-5 June 2009, Beijing, China, viewed 02 March 2010, from http://www.julianmuller.co.za

Nederduitse Gereformeerde Kerk, 2013, Notule vir die 15de Vergadering van die Algemene Sinode van die Nederduitse Gereformeerde Kerk, besigtig op 08 September 2014 by http://www.kerkargief.co.za/doks/acta/AS_Notule_2013.pdf

Niemandt, C.J.P. \& Meiring, P.G.J., 2013, 'Raamwerkdokument oor die missionale aard en roeping van die NG Kerk', verslag aan die Algemene Sinode van die NG Kerk Oktober 2013, besigtig op 8 September 2014, by http://www.ngkerkas.co.za/wp-content/ uploads/2014/02/A-12-7-MISSIONALE-AARD-EN-ROEPING-VAN-DIE-NG-KERK.doc

O'Malley, W.J., 2011, 'Hope for future church', America Magazine 205(9), 28-29, viewed 03 June 2012, from Academic Search Premier, EBSCOhost.

Osmer, R.R., 2008, Practical theology, William B. Eerdmans, Grand Rapids.

Osmer, R.R., 2012, 'Formation in the missional church', in D.J. Zcheile (ed.), Cultivating sent communities: Missional spiritual formation, pp. 29-55, William. B. Eerdmans, Grand Rapids.

Perls, F.S., 1969, Gestalt therapy verbatim, Real People Press, Lafayette, viewed 1 September 2014, from http://www.openlibrary.org

Philippson, P., 2012, Gestalt therapy: Roots and branches - Collected papers, Karnac Books, London.

Schulte, A., 2011, 'Will there be faith?', U.S. Catholic 76(9), 51, viewed 3 June 2012, from Academic Search Premier, Ipswich.

Strommen, M.P. \& Hardel, R.A., 2008, Passing on the faith: A radical model for youth and family ministry, St Mary's Press, Winona.
Truscott, D., 2013, 'Gestalt therapy', in G.R. VandenBos, E. Meidenbauer \& J. FrankMcNeil (eds.), Psychotherapy theories and techniques: A reader, pp. 187-194, Magination Press, Washington.

Van der Merwe, C.N., 2004, Kategese as middel tot heilsekerheid en heilstoe-eiening in konteks van die verbond en die koninkryk, PhD-proefskrif, Departement Praktiese Teologie, Noordwes-Universiteit.

Van Huyssteen, J.W., 1998, Duet or duel?: Theology and science in a postmodern world, Trinity Press International, Pennsylvania.

Van Huyssteen, J.W., 1999, The shaping of rationality: Toward interdisciplinarity in theology and science, William B. Eerdmans Publishing Co., Grand Rapids.

Van Huyssteen, J.W., 2006, Alone in the world?: Human uniqueness in science and theology, William B. Eerdmans Publishing Co., Grand Rapids.

Veldsman, H.J., 2005, Geloofsvorming vanuit 'n familiale perspektief, MDiacverhandeling, Departement Filosofie, Praktiese en Sistematiese Teologie, UNISA.

Walters, T.P., 2004, 'Horizons and hopes: The future of religious education by Thomas H. Groome and Harold Daly Horell', Religious Education 99(2), 207-209, viewed 03 June 2012, from Academic Search Premier, EBSCOhost.

Woldt, A.L. \& Toman, S.M., 2005, 'Prologue-foreword', in A.L. Woldt \& S.M. Toman (eds.) Gestalt therapy: History, theory and practice, pp. ix-xvi, Sage, London.

Wong, A., McAlpine, B. \& Buszowski, F., 2009, 'Learning through shared Christian praxis: Reflective practice in the classroom', Teaching Theology \& Religion 12(4), 305-320, viewed 03 Jun 2012, from Academic Search Premier, Ipswich.

Yontef, G.M., 1993, Awareness, dialogue and process: Essays on Gestalt therapy, The Gestalt Journal Press, Gouldsboro.

Yontef, G.M., 2005, 'Gestalt therapy theory of change', in A.L. Woldt \& S.M. Toman (eds.) Gestalt therapy: History, theory and practice, pp. 81-100, Sage, Thousand Oaks.

Yontef, G.M. \& Jacobs, L., 2014, 'Gestalt therapy' in R.J. Corsini \& D. Wedding (eds.), Current psychotherapies, 10th edn., pp. 299-338, Brooks/Cole, Belmont.

Zscheile, D.J., 2012, 'A missional theology of spiritual formation', in D.J. Zscheile (ed.), Cultivating sent communities: Missional spiritual formation, pp. 1-28, William. B. Eerdmans, Grand Rapids, MI. 